\title{
Chagas disease: morbidity profile in an endemic area of Northeastern Brazil
}

\author{
Cléber de Mesquita Andrade ${ }^{[1],[2], ~ A n t o ̂ n i a ~ C l a ́ u d i a ~ J a ́ c o m e ~ d a ~ C a ̂ m a r a ~}{ }^{[3]}$, \\ Daniela Ferreira Nunes ${ }^{[4]}$, Paulo Marcos da Matta Guedes ${ }^{[5]}$, \\ Wogelsanger Oliveira Pereira ${ }^{[2]}$, Egler Chiari ${ }^{[4]}$, Rosiane Viana Zuza Diniz ${ }^{[1],[6]}$ \\ and Lúcia Maria da Cunha Galvão ${ }^{[1],[4]}$
}

[1]. Programa de Pós-Graduação em Ciências da Saúde, Centro de Ciências da Saúde, Universidade Federal do Rio Grande do Norte, Natal, Rio Grande do Norte, Brasil. [2]. Faculdade de Ciências da Saúde, Universidade do Estado do Rio Grande do Norte, Mossoró, Rio Grande do Norte, Brasil. [3]. Departamento de Análises Clínicas e Toxicológicas, Centro de Ciências da Saúde, Universidade Federal do Rio Grande do Norte, Natal, Rio Grande do Norte, Brasil. [4]. Departamento de Parasitologia, Instituto de Ciências Biológicas, Universidade Federal de Minas Gerais, Belo Horizonte, Minas Gerais, Brasil. [5]. Departamento de Microbiologia e Parasitologia, Centro de Biociências, Universidade Federal do Rio Grande do Norte, Natal, Rio Grande do Norte, Brasil. [6]. Departamento de Clínica Médica, Centro de Ciências da Saúde, Universidade Federal do Rio Grande do Norte, Natal, Rio Grande do Norte, Brasil.

\begin{abstract}
Introduction: This study evaluated the clinical forms and manifestation severities of Chagas disease among serologically reactive individuals from Western Rio Grande do Norte (Northeastern Brazil). Methods: This cross-sectional study included 186 adults who were evaluated using electrocardiography, echocardiography, chest radiography, and contrast radiography of the esophagus and colon. A clinical-epidemiological questionnaire was also used. Results: The indeterminate, cardiac, digestive, and cardiodigestive clinical forms of Chagas disease were diagnosed in 51.6\% (96/186), 32.2\% (60/186), 8.1\% (15/186) and $8.1 \%(15 / 186)$ of the participants, respectively. Heart failure (functional classes I-IV) was detected in $7.5 \%(14 / 186)$ of the participants, and 36.4\% (24/66), 30.3\% (20/66), 15.2\% (10/66), 13.6\% (9/66), and 4.5\% (3/66) of the patients were at stage A, B1, B2, C, and D, respectively. Dilated cardiomyopathy and electrocardiographic changes were detected in $10.2 \%(19 / 186)$ and $48.1 \%(91 / 186)$ of the participants, respectively. Apical aneurysm was diagnosed in 10.8\% (20/186) of the participants, and other changes in the segmental myocardial contractility of the left ventricle were diagnosed in 33.9\% (63/186) of the participants. Megaesophagus (groups I-IV) was observed in 7\% (13/186) of the participants, megacolon (grades 1-3) was detected in $12.9 \%$ (24/186) of the participants, and both organs were affected in 29.2\% (7/24) of the megacolon cases. Conclusions: We detected various clinical forms of Chagas disease (including the digestive form). Our findings indicate that clinical symptoms alone may not be sufficient to exclude or confirm cardiac and/or digestive damage, and the number of patients with symptomatic clinical forms may be underestimated.
\end{abstract}

Keywords: Trypanosoma cruzi. Chagas disease. Chagasic cardiomyopathy. Megaesophagus. Megacolon.

\section{INTRODUCTION}

Chagas disease $(\mathrm{ChD})$ remains a major public health challenge in Latin America, where it currently affects 5.7 million individuals, with the largest numbers observed in Argentina, Brazil, and Mexico ${ }^{(1)}$. The clinical manifestations of $\mathrm{ChD}$ exhibit regional variations that are associated with different factors and are related to the parasite and/or host as the main cause of the chronic phase of the disease ${ }^{(2)}$. The digestive form is considered common in central Brazil and Chile, although it is practically non-existent in Venezuela and Central America ${ }^{(3)}$.

Corresponding author: Dr. Cléber de Mesquita Andrade. Faculdade de Ciências da Saúde/UERN. Rua Atirador Miguel Antônio da Silva Neto s/n, Aeroporto, 59607-360 Mossoró, Rio Grande do Norte, Brasil.

Phone: 5584 3315-2248; Fax: 5584 3317-5837

e-mail: mesquitacleberrn@gmail.com

Received 11 July 2015

Accepted 5 October 2015
The forms of $\mathrm{ChD}$ are usually estimated based on clinical signs and symptoms, and without performing esophagus and colon contrast radiography, due to the difficulty of performing these exams. Therefore, in northeastern Brazil, an initial diagnosis of the digestive form has typically been based on the signs and symptoms of intestinal constipation and/ or evidence of fecalomas ${ }^{(4)}$. In contrast, the indeterminate form is characterized by the absence of symptoms that are compatible with $\mathrm{ChD}$, and common diagnostic testing is not normally performed, such as conventional serology,12-lead electrocardiography, and radiography of the chest, esophagus, and colon ${ }^{(5)}$. In endemic areas, $50-70 \%$ of patients present with the indeterminate clinical form and $2-5 \%$ of these individuals evolve to a known clinical form, with approximately $20-30 \%$ of patients developing the cardiac form, 5-8\% developing the esophageal form, and 4-6\% developing the intestinal form ${ }^{(6)(7)(8)}$. The high mortality rateis due to chronic $\mathrm{ChD}$ cardiomyopathy (CCC), which is characterized by manifestations that include complex arrhythmias, heart failure, and thromboembolic 
events $^{(9)}$. The digestive form is characterized by digestive symptoms of megaesophagus and/or megacolon, which are due to inflammation and fibrosis of the esophagus and/or colon that results in destruction of the autonomic nervous system and subsequent organ dysfunction ${ }^{(10)}$.

The first scientific description of Trypanosoma cruzi infection in the State of Rio Grande do Norte (RN) reported a prevalence of $15.5 \%^{(11)}$. More recent data support an estimated seroprevalence of $6.5 \%$ for chagasic infection in the Western mesoregion of RN, although that study did not examine the clinical forms of $\mathrm{ChD}^{(12)}$. Therefore, the present study aimed to characterize the different clinical forms of $\mathrm{ChD}$, its evolution among seroreactive individuals from different municipalities in western RN, and its association with disease severity.

\section{METHODS}

\section{Study area}

The State of RN is located in Northeastern Brazil, and consists of 167 municipalities that are distributed throughout East, Agreste, Central, and West mesoregions. The present study was performed in the West mesoregion, which covers $>40 \%$ of RN's surface area $\left(53,077.3 \mathrm{~km}^{2}\right)$ (Figure 1).This area was selected because a previous seroepidemiological survey was performed in this region during 2007-2009, and reported an estimated $\mathrm{ChD}$ prevalence of $6.5 \%{ }^{(12)}$.

\section{Study population and protocol}

A total of 215 individuals from 15 municipalities were invited to participate in this cross-sectional study between 2011 and 2013. However, only 186 individuals (23-78 years old) were ultimately included, as various patients were excluded due to disabilities, unwillingness to be examined, and other heart pathologies (e.g., ischemic, valvular, and hypertensive heart disease). Among the 186 included individuals, 83 individuals ( 38 men and 45 women) had participated in the previous seroepidemiological survey ${ }^{(12)}$, and 103 individuals (54 men and 49 women) had spontaneously demanded testing at the $\mathrm{ChD}$ outpatient clinic of the State University of Rio Grande do Norte. The patients who spontaneously demanded testing generally presented with two or more previous reactive serological tests for T. cruzi (e.g., at blood banks or primary health centers), and had been instructed to seek treatment at our outpatient clinic. Very few patients spontaneously demanded testing due to clinical symptoms.

All patients completed the same clinical-epidemiological questionnaire, which evaluated their lifestyle and concomitant diseases, and underwent a physical examination. Heart failure was classified according to the New York Heart Association criteria $^{(13)}$ and categorized according to the American College of Cardiology/American Heart Association classifications that were adapted for $\mathrm{ChD}^{(14)(15)}$.

Plain posteroanterior and lateral chest radiography were performed to evaluate the cardiac silhouette, signs of pulmonary

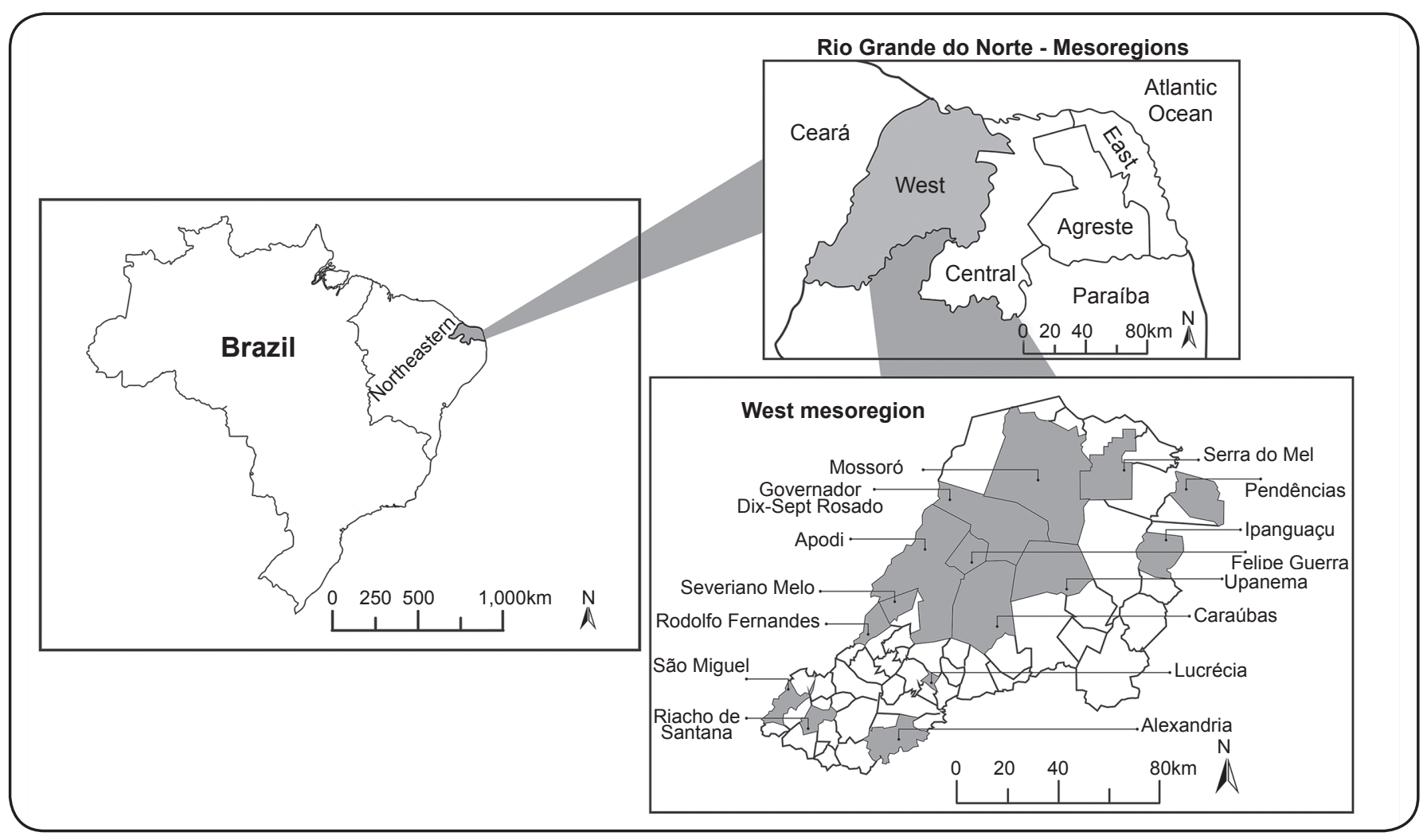

FIGURE 1 - A map of Brazil with the State of Rio Grande do Norte, the Western mesoregion (in gray), and the municipalities that were evaluated. 
congestion, and cardiothoracic ratio. The patient's clinical form was classified based on the assumption that a cardiothoracic ratio of $>0.5$ was abnormal ${ }^{(16)}$. Contrast radiography of the esophagus was performed to classify the esophagus into four groups ${ }^{(17)}$, and contrast radiography of the colon was performed as previously described ${ }^{(18)}$. The diameter of the rectum was measured in the right lateral decubitus position, and the sigmoid colon was measured in the dorsal decubitus position, or in the ventral decubitus position if necessary ${ }^{(19)}$. The sigmoid colon was classified into four grades $(0-3)^{(20)}$, with some modifications.

A portable electrocardiography device (EP3 2008; Dixtal ${ }^{\circledR}$, Brazil) was used for 12-lead electrocardiography. All electrocardiographic recordings were evaluated by the same examiner, and scored based on the Minnesota Code that was modified and adapted for $\mathrm{ChD}^{(21)}$.

All Doppler echocardiography examinations were performed by the same examiner, using conventional views and their variations

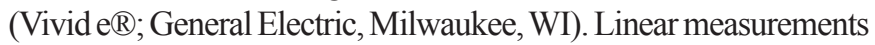
of the cardiac chambers and left ventricle ejection fraction were visually estimated and confirmed. The cardiac chambers were evaluated according to the recommendations of the American Society of Echocardiography ${ }^{(22)}$. Simpson's modified method ${ }^{(23)}$ was used when changes in segmental contractility were observed, and the Teichholz formula ${ }^{(24)}$ was used in the absence of any changes.

\section{Statistical analysis}

This study used a convenience sample. Data were reported as mean \pm standard deviation (SD). The proportions of the $\mathrm{ChD}$ forms were compared before and after the completion of contrast radiography. The chi-square test was used to analyze the associations between the clinical forms of $\mathrm{ChD}$ and the patients' age; testing type (seroepidemiological survey vs. spontaneous demand); symptoms of palpitations, dysphagia, and constipation; and the associations between dysphagia and megaesophagus and constipation and megacolon, after the completion of contrast radiography. The prevalence ratios (PRs) and their respective confidence intervals (CIs) were calculated for the associated data. The parametric Student $t$ test was used to evaluate the differences between the mean values of the sigmoid colon and rectum measurements for men and women. Differences were considered significant at a p-value of $\leq 0.05$, and all analyses were performed using Statistical Package for the Social Sciences (SPSS) software (version 20.0; SPSS Inc. Chicago, IL, USA).

\section{Ethical considerations}

Informed consent for this study was obtained from all participants, and the study's design was approved by the Research Ethics Committee of the State University of Rio Grande do Norte (protocol no. 027.2011). All experiments were performed in accordance with the human experimental guidelines of the Brazilian Ministry of Health and the Declaration of Helsinki.

\section{RESULTS}

All participants were from rural areas and were currently residing or had previously resided in packed-earth houses; agricultural work was the predominant occupation. Approximately $50.5 \%$ of the participants were women, the mean age was $49 \pm 12$ years, and $>70 \%$ of patients were illiterate or only had access to elementary/middle school education (which was not always completed) (Table 1). The indeterminate, cardiac, digestive, and cardiodigestive forms of $\mathrm{ChD}$ were observed in $51.6 \%$ (96/186), 32.2\% (60/186), $8.1 \%(15 / 186)$, and $8.1 \%(15 / 186)$ of the participants, respectively. Based on only digestive symptoms (no contrast radiography), the proportions were $59.1 \%, 33.3 \%, 3.3 \%$, and $4.3 \%$ for the indeterminate, cardiac, digestive, and cardiodigestive forms of $\mathrm{ChD}$, respectively.

When we compared the prevalence ratios of the radiographyconfirmed and estimated clinical forms, significant differences for the digestive form (PR: $2.45 ; 95 \%$ CI: 2.18-2.73) and the cardiodigestive form (PR: 1.88; 95\% CI: 1.61-2.16). There were no significant differences for the indeterminate form (PR: 0.87 ; 95\% CI: 0.60-1.15) or the cardiac form (PR: $0.97 ; 95 \%$ CI: 0.69-1.24). We also did not observe any significant differences when we compared the testing types (seroepidemiological survey vs. spontaneous demand) among the various age groups $(\mathrm{p}=0.6385)($ Table 2).

Chest radiography revealed cardiomegaly in $10.2 \%(19 / 186)$ of the participants, which provided a sensitivity of $25.3 \%$ $(19 / 75)$ for identifying heart involvement in the cardiac and cardiodigestive clinical forms.

Contrast radiography revealed megaesophagus in 7\% (13/186) of the participants, with group I observed in 7 (53.8\%) patients, group II observed in 4 (30.8\%) patients, group III observed in $1(7.7 \%)$ patient, and group IV observed in $1(7.7 \%)$ patient. No significant sex-related differences between the megaesophagus groups were observed $(p=0.27)$ (Figure 2A). Dysphagia was diagnosed in $6.5 \%(12 / 186)$ of the participants, and patients with megaesophagus II and III reported that dysphagia limited their quality of life. However, this symptom did not discriminate between patients that had normal esophageal radiography findings with dysphagia and patients in the megaesophagus group I who did not have dysphagia $(p=0.07)$. Approximately $5 \%$ of the participants complained of occasional dysphagia, despite exhibiting normal esophageal radiography findings. However, patients with the digestive and cardiodigestive forms exhibited the greatest probability of having dysphagia (PR: 3.2; 95\% CI: 2.07-4.33; $\mathrm{p}=0.006$ ), compared to patients who had the indeterminate form. Esophageal radiography revealed three characteristic features: significant dilatation and elongation of the esophagus, food debris due to achalasia of the lower esophagus (the rat's tail sign; even in patients who had fasted for 12h), and folding over the diaphragm (Figure 2B).

Colon contrast radiography revealed megacolon in $12.9 \%$ (24/186) of the participants, with grade 1 observed in 17 (70.8\%) patients, grade 2 observed in $6(25 \%)$ patients, and grade 3 observed in $1(4.2 \%)$ patient. Both sexes exhibited similar distributions $(p=0.42)$ (Figure 2C). Constipation was detected in $8.6 \%(16 / 186)$ of the participants, although this symptom did not discriminate between patients with grade 0 or grade 1 sigmoid colon $(\mathrm{p}=0.23)$. Approximately $7 \%$ of the participants 
TABLE 1 - Epidemiological variables from 186 individuals with reactive conventional serology results for Trypanosoma cruzi.

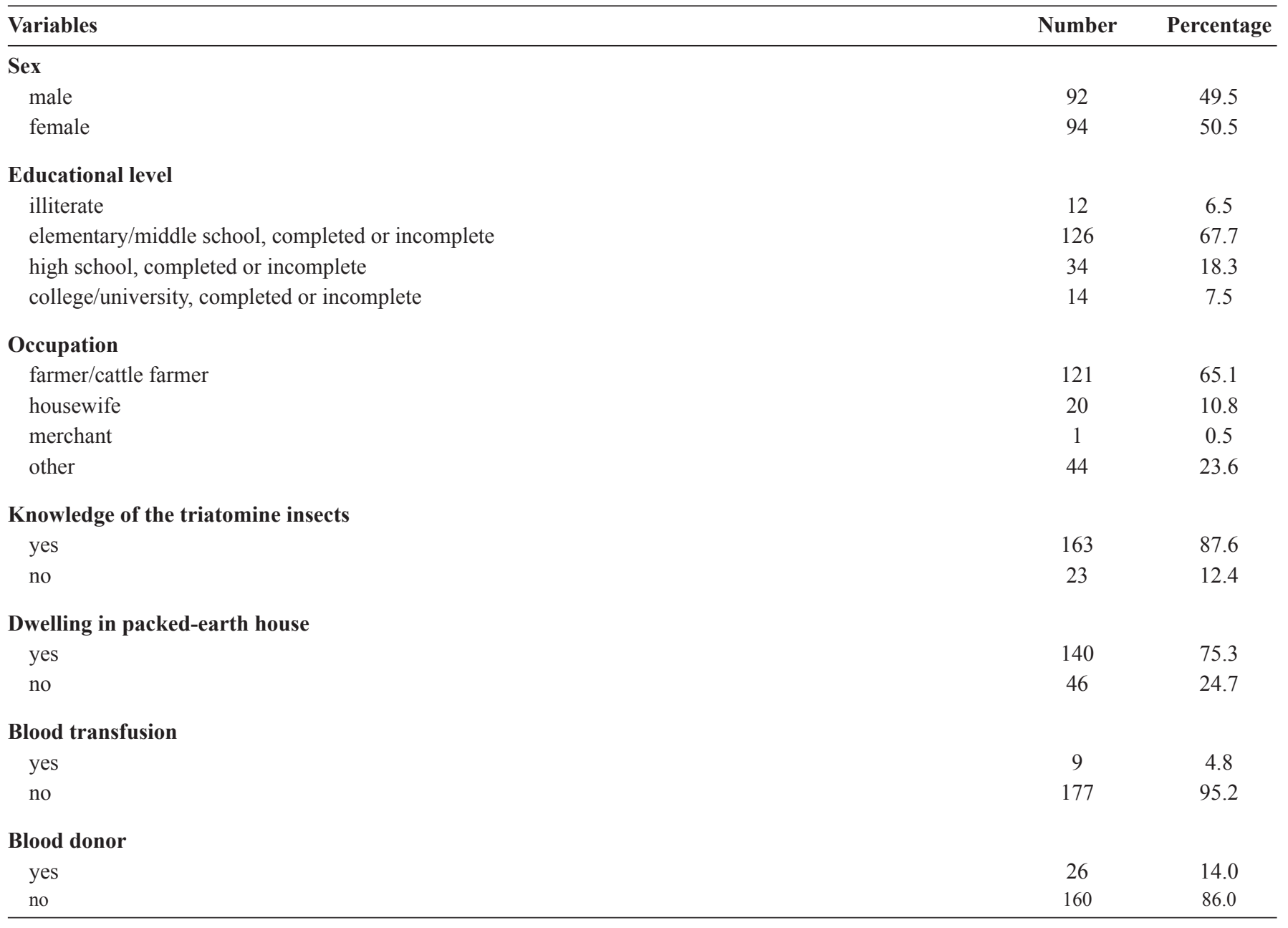

TABLE 2 - Distribution of clinical forms according to age and testing type among 186 patients with chronic-phase Chagas disease.

\begin{tabular}{|c|c|c|c|c|c|c|c|c|c|c|c|}
\hline \multirow{2}{*}{ Age range, years } & \multirow{2}{*}{ Testing } & \multicolumn{10}{|c|}{ Clinical form } \\
\hline & & $\mathbf{n}$ & $\%$ & $\mathbf{n}$ & $\%$ & n & $\%$ & $\mathbf{n}$ & $\%$ & $\mathbf{n} / \mathbf{T}$ & $\%$ \\
\hline \multirow[t]{2}{*}{$20-29$} & SS & 4 & 33.3 & 2 & 16.7 & 1 & 8.3 & 1 & 8.3 & $8 / 12$ & 66.7 \\
\hline & $\mathrm{SD}$ & 2 & 16.7 & 2 & 16.7 & 0 & 0.0 & 0 & 0.0 & $4 / 12$ & 33.3 \\
\hline \multirow[t]{2}{*}{$40-49$} & SS & 12 & 23.1 & 7 & 13.5 & 2 & 3.8 & 2 & 3.8 & $23 / 52$ & 44.2 \\
\hline & SD & 16 & 30.8 & 11 & 21.2 & 2 & 3.8 & 0 & 0.0 & $29 / 52$ & 55.8 \\
\hline \multirow[t]{2}{*}{$50-59$} & SS & 9 & 20.0 & 6 & 13.4 & 1 & 2.2 & 1 & 2.2 & $17 / 45$ & 37.8 \\
\hline & $\mathrm{SD}$ & 13 & 28.9 & 10 & 22.2 & 3 & 6.7 & 2 & 4.4 & $28 / 45$ & 62.2 \\
\hline \multirow[t]{2}{*}{$70-79$} & SS & 2 & 20.0 & 1 & 10.0 & 1 & 10.0 & 3 & 30.0 & $7 / 10$ & 70.0 \\
\hline & SD & 0 & 0.0 & 2 & 20.0 & 0 & 0.0 & 1 & 10.0 & $3 / 10$ & 30.0 \\
\hline
\end{tabular}

SS: seroprevalence survey; SD: spontaneous demand; n: number of patients; T: total number of patients in the age range. 


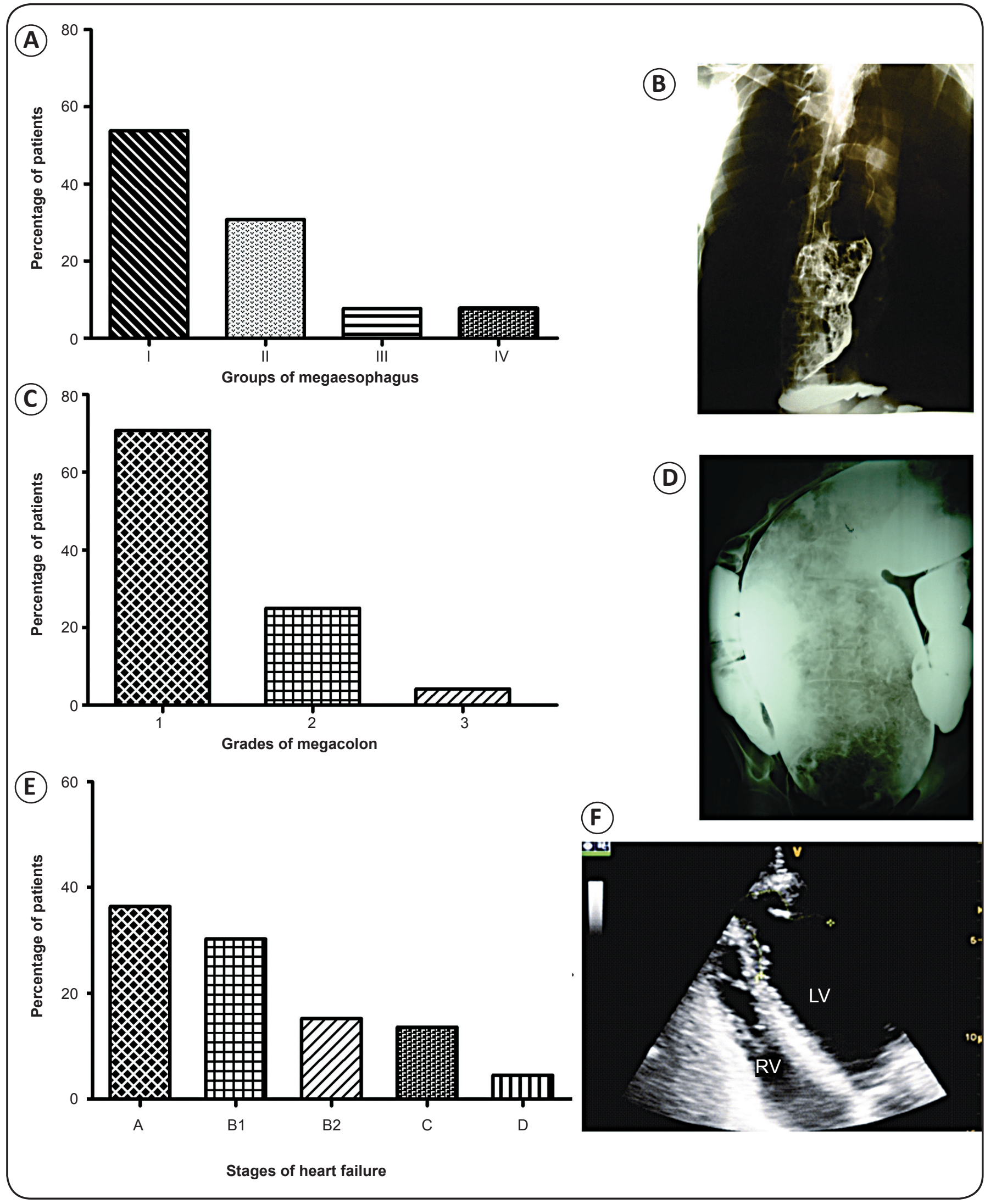

FIGURE 2 - The clinical evolution of Chagas disease. A. Patients were categorized into different groups of megaesophagus, and B. A contrast radiography image of the characteristic esophagus appearance is shown. C. Patients were categorized into different grades of megacolon, and D. A contrast radiography image of the characteristic colon appearance is shown. E. Patients were categorized according to heart failure stage, and F. Echocardiography reveals a characteristic left ventricle apical aneurysm. LV: left ventricle; RV: right ventricle. 
with grade 0 sigmoid colon also experienced constipation. In contrast, patients with the digestive/cardiodigestive forms exhibited a high probability of constipation (PR: 2.56; 95\% CI: $1.24-3.87 ; p=0.001)$, compared to patients who had the indeterminate form. The smallest sigmoid colon diameter was $2.5 \mathrm{~cm}$, the largest diameter was $19.0 \mathrm{~cm}$, and the mean diameter was $4.9 \pm 1.8 \mathrm{~cm}$. The smallest rectum diameter was $3.0 \mathrm{~cm}$, the largest diameter was $15.0 \mathrm{~cm}$, and the mean diameter was $5.7 \pm 1.4 \mathrm{~cm}$. Among the patients with different megacolon grades, 7 patients also exhibited megaesophagus. Colon contrast radiography revealed significant dilatation of the sigmoid colon and rectum in patients with chronic constipation, and abdominal palpation revealed the presence of fecal impaction (Figure 2D).

Heart failure functional classification revealed that $7.5 \%$ $(14 / 186)$ of the participants had dyspnea, with $8(57.1 \%)$ of these patients being class I, $2(14.3 \%)$ patients being class II, $1(7.1 \%)$ patient being class III, and $3(21.5 \%)$ patients being class IV. The stage classification that was adapted for $\mathrm{ChD}$ revealed that $36.4 \%(24 / 66)$ of patients were in stage A, $30.3 \%$ $(20 / 66)$ of patients were in stage B1, 15.2\% (10/66) of patients were in stage B2, $13.6 \%(9 / 66)$ of patients were in stage $C$, and $4.5 \%(3 / 66)$ of patients were in stage D (Figure 2E). Symptoms of palpitation at rest were identified in $15 \%(28 / 186)$ of the participants, and echocardiography in the modified apical view revealed left ventricular aneurysm in patients with chagasic cardiomyopathy and stage $\mathrm{C}$ heart failure (Figure 2F).
Although electrocardiographic changes are not always suggestive of cardiac $\mathrm{ChD}$, these changes were detected in $48.9 \%(91 / 186)$ of the participants, although they were not associated with any specific cardiac symptoms. Right bundle branch block (RBBB) was present in $30.8 \%$ (28/91) of the patients with electrocardiographic changes. Low-amplitude signals in the QRS complex were identified in $27.5 \%$ (21/91) of these patients, and the association of RBBB with left anterior fascicular block (LAFB) was observed in 17.6\% (16/91) of these patients (Figure 3).

Echocardiography revealed left and right ventricle systolic dysfunction in $14 \%(26 / 186)$ and $7 \%(13 / 186)$ of the participants, respectively. Among the 26 patients with left ventricle systolic dysfunction, the dysfunction was discrete in $42.3 \%(11 / 26)$ of the patients, moderate in 50\% (13/26) of the patients, and severe in $7.7 \%(2 / 26)$ of the patients. Changes in the left ventricle segment contractility were observed in $33.9 \%$ (63/186) of the participants, with $46.7 \%(28 / 60)$ of patients having the cardiac form, $66.7 \%(10 / 15)$ of patients having the cardiodigestive form, $22.9 \%$ (22/96) of patients having the indeterminate form, and 20\% (3/15) of patients having the digestive form. The most frequently affected left ventricle segment was the apex $(31 / 63 ; 49.2 \%)$, which was followed by the posteroinferior segment $(21 / 63 ; 33.3 \%)$ and global involvement $(4 / 63 ; 6.3 \%)$. Left ventricular apical aneurysm was detected in $10.8 \%(20 / 186)$ of the participants, and $55 \%$ $(11 / 20)$ of these patients had the cardiac form, $20 \%(4 / 20)$ of

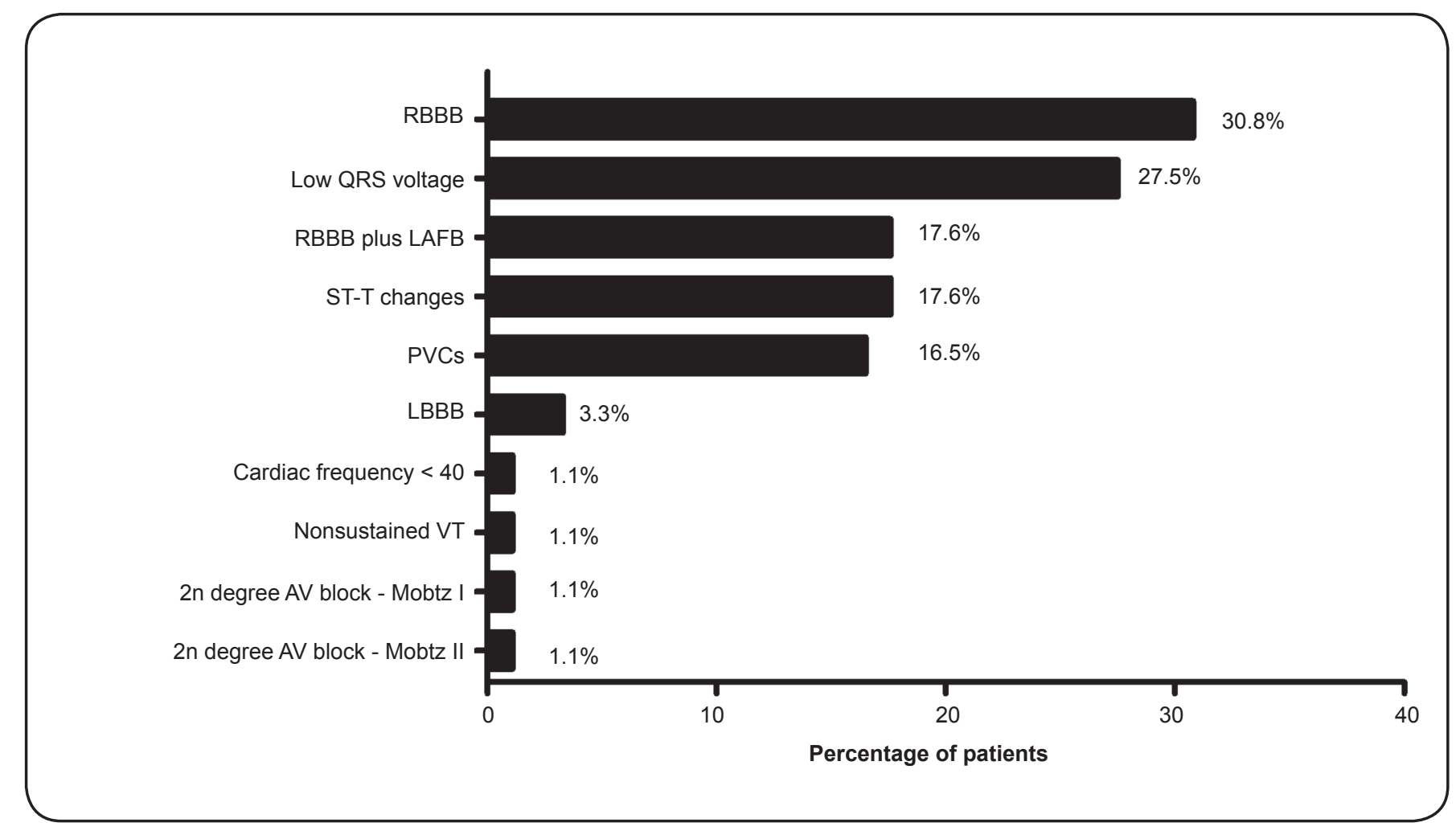

FIGURE 3 - Distribution of the ten most frequent electrocardiographic changes among 91 chagasic patients. Note: more than one change was possible in the same patient. RBBB: right bundle branch block; LAFB: left anterior fascicular block; PVCs: premature ventricular complexes; LBBB: left bundle-branch block; VT: ventricular tachycardia; 2n: second; AV: atrioventricular. 
these patients had the cardiodigestive form, 20\% (4/20) of these patients had the indeterminate form, and 5\% (1/20) of these patients had the digestive form. Right ventricular apical aneurysm was diagnosed in $5.4 \%(10 / 186)$ of the participants.

\section{DISCUSSION}

Studies regarding chronic $\mathrm{ChD}$ in endemic areas have typically been conducted by stratifying the clinical forms using the patients' clinical symptoms, and without the use of contrast radiography. This is the first study to characterize the clinical forms of $\mathrm{ChD}$ and the severity of its clinical manifestations among patients with chronic infection in Western RN. Our findings revealed that very few participants were $<30$ years old, which is likely due to recent improvements in rural dwellings, vector control programs ${ }^{(25)}$, and population movement into more urban areas. The small number of participants who were $>60$ years old may be explained by the evolution of the indeterminate form in to a known clinical form (e.g., the cardiac form), which would increase the risk of fatal complications ${ }^{(26)}$.

We did not observe any significant difference in the clinical forms according to the testing type for each age range. However, the indeterminate form of $\mathrm{ChD}$ was predominant ( $>50 \%$ of the participants), which confirms the findings of other studies that examined outpatients ${ }^{(27)(28)(29)}$. Nevertheless, the characterization of $\mathrm{ChD}$ is difficult in rural populations, as many small Brazilian towns do not have the equipment for classic barium enema radiography ${ }^{(19)}$. Therefore, most authors have not radiographically examined the colon, and have assumed that treatment of the digestive manifestations of $\mathrm{ChD}$ should be directed to the symptomatic and more advanced forms ${ }^{(30)}$. This approach likely results in underestimation of the prevalences for the digestive and cardiodigestive forms. Thus, clinical symptoms (e.g., dysphagia and constipation) are insufficient to identify patients with early-stage digestive and cardiodigestive forms. In this context, early identification of digestive lesions can motivate lifestyle changes (e.g., in hygiene and diet) and indicate multidisciplinary care, which might prevent progression to a more severe form of $\mathrm{ChD}$.

Megaesophagus was detected at different stages in the present study, which supports the data from other Brazilian regions $^{(31)}$ and studies that reported high prevalences of the digestive form in central Brazil and other South American countries $^{(32)}$. Although cases of grade 2-3 megacolon were diagnosed in the present study, the majority of cases were grade 1 with a sigmoid colon diameter of $>5.0 \mathrm{~cm}$. Using the same technique, but only considering megacolon with a sigmoid colon diameter of $\geq 7.0 \mathrm{~cm}$, resulted in a lower prevalence ${ }^{(33)}$. Thus, all patients with grade 2-3 megacolon had $\mathrm{ChD}$, although patients with grade 1 megacolon may or may not exhibit intestinal involvement of $\mathrm{ChD}$. Various factors may be involved in the genesis of the digestive form, which include intrinsic denervation that is triggered by $T$. cruzi along the nerve plexus of the esophagus and intestine, which and which can result in denervation of the autonomic parasympathetic system ${ }^{(34)}$. This denervation affects these organs' functions, and especially those of the esophagus and sigmoid colon, which require coordination to propel their contents through their distal sphincters. The climax of megaesophagus and megacolon is the decompensated stage of the disease ${ }^{(35)}$, which can be triggered by various parasite strains $^{(36)}$ or a cross-reaction between T. cruzi antigens and the host tissues ${ }^{(37)}$.

The most important clinical presentation of chronic $\mathrm{ChD}$ is CCC, which has been detected in patients with similar morbidity rates through different endemic areas of Brazil and Colombia ${ }^{(38)(39)}$. However, lower morbidity rates are observed in other endemic regions of Latin America ${ }^{(40)(41)}$. In the present study, cardiomegaly was exclusively present with the cardiac and cardiodigestive forms, which is in agreement with previously reported data ${ }^{(42)(43)}$. However, the low sensitivity of chest radiography for identifying cardiac involvement is related to the right ventricle being one of the cardiac chambers that is most affected by $\mathrm{CCC}^{(44)}$. As this is the most anterior chamber of the heart, its enlargement may not noticeably increase the cardiothoracic ratio, which precludes the identification of the cardiomegaly.

The participants with $\mathrm{ChD}$ exhibited all functional classifications and stages of heart failure, although the patients were predominantly functional class I and stage A, which is characteristic of an outpatient sample. However, the presence of patients in functional classes III-IV and stages C-D indicates that $\mathrm{ChD}$ in this region is more severe than findings from northern Brazil ${ }^{(45)}$. In this context, CCC is associated with a worse prognosis and a survival rate that is one-half of the rates for cardiomyopathies of non-inflammatory etiology (e.g., dilated cardiomyopathy and ischemic heart disease) ${ }^{(46)}$. Studies in Brazil and Venezuela have also reported that higher functional classes are associated with higher mortality rates among patients with $\mathrm{CCC}^{(47)(48)}$, with sudden death, heart failure, and ischemic stroke being the main mechanisms of death in patients with $\mathrm{ChD}^{(49)(50)}$.

Our findings regarding electrocardiographic changes, such as RBBB and LAFB, are in agreement with the previous studies and are the most characteristic changes of the disease in endemic areas ${ }^{(51)}$. The higher prevalence of RBBB, compared to left bundle branch block, is likely related to the anatomy of the heart's conduction system, as in the classical description ${ }^{(52)}$. The right branch of the His-Purkinje system is long, slender, and presents a large intramyocardial course, while the left branch has many sub-branches and takes a subendocardial course along its entire length. Ventricular arrhythmia has been previously described ${ }^{(53)}$, and may be caused by cardiac conduction system lesions that are related to the degree of ventricular dysfunction and to the increased risk of cardiovascular death ${ }^{(54)}$.

Changes in segmental myocardial contractility were predominantly in the left ventricular apex and posterior basal segment, even in patients with the indeterminate form, which confirms the findings of previous studies ${ }^{(55)(56)}$. Interestingly, the indeterminate form was assigned to patients who fulfilled the related criteria in the present study, even if they exhibited contractility segmental changes during echocardiography. However, we believe that these patients should be classified as having the cardiac form, as this classification may facilitate the 
use of more effective prophylactic and/or therapeutic measures. Furthermore, left ventricular apical aneurysm was more common in this study than the reported frequency in central Brazil $^{(43)}$, and was less common than the reported frequency in southeastern Brazil ${ }^{(57)}$. Although left ventricular apical aneurysm is not characteristic of the cardiac form, it was more common among patients with this clinical form, which may be related to its severity and the increased risk of ischemic stroke and/or death among these patients ${ }^{(58)(59)}$.

Unfortunately, the factors that determine the variability of the clinical forms of $\mathrm{ChD}$, pathogenesis, and patterns of development remain unclear. It is possible that these changes may be associated with the wide geographical dispersion of homogeneous $T$. cruzi genotypes from different parasite sources and groups that have been identified throughout the municipalities of $\mathrm{RN}^{(60)}$. As a result, the forms of chronic $\mathrm{ChD}$ seem to be directly associated with discrete typing units of $T$. cruzi, which might explain the observed differences in the expression of anti-inflammatory and pro-inflammatory cytokines, and the specific immune responses ${ }^{(61)}$. Furthermore, this variability may depend on tissue-specific responses and the intensities of the parasitism, inflammatory response, and immune response ${ }^{(62)(63)}$. Moreover, familial aggregation of CCC cases has been well documented, which suggests that genetic components are involved in patients' susceptibility to cardiomyopathy ${ }^{(64)}$.

In conclusion, among patients from Western $\mathrm{RN}$, we believe that approximately one-quarter of patients who are diagnosed with the indeterminate form of $\mathrm{ChD}$ should be considered to potentially have the cardiac form or silent heart disease. This approach would decrease the prevalence of the indeterminate form and alter the therapeutic management of these patients, which might subsequently reduce the prevalence of more severe complications. Furthermore, patients' clinical symptoms may not be sufficient to confirm or rule out a diagnosis of cardiac and/or digestive involvement in chronic ChD. Moreover, isolated digestive and cardiodigestive forms were detected in both symptomatic and asymptomatic patients, with different groupings and grades of megaesophagus and megacolon. Thus, while ignoring any potential underdiagnosis, approximately onethird of patients were diagnosed with the cardiac form of $\mathrm{ChD}$, which involved different types and degrees of atrioventricular and ventricular block, several segmental contractility alterations, and varying degrees of heart failure. These findings indicate that the cardiac form may be the most relevant form of chronic $\mathrm{ChD}$, as it was responsible for more severe clinical outcomes. Nevertheless, prospective cohort studies are needed to confirm our findings in this endemic area, especially among patients with the indeterminate form. Furthermore, studies are needed to evaluate the potential immunological, clinical, and/or genetic markers from the host and/or parasite, which may contribute to improving the prognosis of these clinical manifestations. Moreover, interventional studies are needed to examine the etiology of, and damage due to $\mathrm{ChD}$ - related manifestations in the cardiovascular and digestive systems.

\section{ACKNOWLEDGMENTS}

The authors are grateful to the participants involved in this study, to the health authorities and agents of the Municipal Health Secretariats of the west of the State of Rio Grande do Norte for their indispensable support for the field activities during the development of this survey. We would also like to express to thank to the Clinical Center West Clio for their unconditional support during this study, to Galttieri Tavares Ferreira for his statistical analysis and to Philip S.P. Badiz for his critical reading and revision of the manuscript.

\section{CONFLICT OF INTEREST}

The authors declare that there is no conflict of interest.

\section{FINANCIAL SUPPORT}

This work was supported by research grants from the Conselho Nacional de Desenvolvimento Científico e Tecnológico/ Ministério de Ciência, Tecnologia (MCT/CNPq) number 472251/2010-4 (EC); MCTI/CNPq/MS-SCTIE-Decit number 404056/2012-1 (LMCG); Programa Nacional de Incentivo à Parasitologia Básica/Coordenação de Aperfeiçoamento de Pessoal de Nivel Superior (CAPES) grant number 23038.005288/2011-48(ACJC); research fellowships from the CNPq (LMCG, EC and PMMG) and scholarship from the CAPES (CMA).

\section{REFERENCES}

1. World Health Organization (WHO). Chagas disease in Latin America: an epidemiological update based on 2010 estimates. Weekly Epidemiological Record 2015; 90:33-44.

2. Macedo AM, Machado CR, Oliveira RP, Pena SD. Trypanosoma cruzi: genetic structure of populations and relevance of genetic variability to the pathogenesis of Chagas disease. Mem Inst Oswaldo Cruz 2004; 99:1-12

3. Luquetti AO, Miles MA, Rassi A, Rezende JM, Souza A, Povoa M, et al. Trypanosoma cruzi; zymodeme associated with acute and chronic Chagas' disease in central Brazil. Trans R Soc Trop Med Hyg 1986; 80:462- 470.

4. Macêdo V. Influência da exposição à reinfecção na evolução da doença de Chagas (estudo longitudinal de cinco anos). Rev Patol Trop 1976; 5:33-116.

5. Revista da Sociedade Brasileira de Medicina Tropical. Primeira Reunião de Pesquisa Aplicada em Doença de Chagas. Validade do conceito de forma indeterminada da doença de Chagas. Rev Soc Bras Med Trop 1985; 18:46.

6. Raia A, Campos OM. Megacólon - contribuição ao estudo de sua patogenia e tratamento. Rev Med Cirurg São Paulo 1955; 15 : $392-560$

7. Macêdo VO. Forma indeterminada da doença de Chagas. J Bras Med 1980; 38:34-40.

8. Dias JCP. Doença de Chagas em Bambuí, Minas Gerais, Brasil. Estudo clínico- epidemiológico a partir da fase aguda, entre 1940 
e 1982, 1982, 401p. (Doctor's Thesis). Universidade Federal de Minas Gerais, 1982, Belo Horizonte.

9. Dias JCP. Natural history of Chagas' disease. Arq Bras Cardiol 1995; 65:359-366.

10. Rezende JM. Forma digestiva da moléstia de Chagas. Rev Goiana Med 1959; 5:193-227.

11. Lucena DT, Lima ET. Epidemiologia da doença de Chagas no Rio Grande do Norte, III - A infecção humana determinada pela reação de Guerreiro Machado. Rev Bras Malariol D Trop 1962; 15:361-366.

12. Brito CRN, Sampaio GHF, Câmara ACJ, Nunes DF, Azevedo PRM, Chiari E, et al. Seroepidemiology of Trypanosoma cruzi infection in the semiarid rural zone of the State of Rio Grande do Norte, Brazil. Rev Soc Bras Med Trop 2012; 45:346-352.

13. The Criteria Committee of the New York Heart Association. New York Heart Association Functional Classification. In: Nomenclature and criteria for diagnosis of diseases of the heart and great vessels, editor. $9^{\text {th }}$ ed. Boston: Little, Brown and Company; 1994. p. 253-256.

14. Ministério da Saúde. Brazilian Consensus on Chagas disease. Rev Soc Bras Med Trop 2005; 38:7-29.

15. Xavier SS, Sousa AS, Hasslocher-Moreno A. Application of the New Classification of Cardiac Insufficiency (ACC/AHA) in Chronic Chagas Cardiopathy: A critical analysis of the survival curves. Rev SOCERJ 2005; 18:227-232.

16. Danzer CS. The cardiothoracic ratio: an index of cardiac enlargement. Am J Med Sci 1919; 157:513-521.

17. Rezende JM, Lauar KM, Oliveira A. Clinical and radiological aspects of aperistalsis of the esophagus. Rev Bras Gastroenterol $1960 ; 12: 247-262$.

18. Ximenes CA, Rezende JM, Moreira H, Vaz MGM. Técnica simplificada para diagnóstico radiológico do megacólon chagásico. Rev Soc Bras Med Trop 1984; 17:23.

19. Castro C, Hernandez EB, Rezende JM, Prata A. Radiological study on megacolon cases in an endemic area for Chagas disease. Rev Soc Bras Med Trop 2010; 43:562-566.

20. Silva AL, Giacomin RT, Quirino VA, Miranda ES. Proposta de Classificação do megacólon chagásico através do enema opaco. Rev Col Bras Cir 2003; 30:4-10.

21. Maguire JH, Mott KE, Souza, JA, Almeida EC, Ramos NB, Guimarães AC. Electrocardiographic classification and abbreviated lead system for population-based studies of Chagas' disease. Bull Pan Am Health Org 1982; 16:47-58.

22. Lang RM, Bierig M, Devereux RB, Flachskampf FA, Foster E, Pellikka PA, et al. Recommendations for chamber quantification: a report from the American Society of Echocardiography's Guidelines and Standards Committee and the Chamber Quantification Writing Group, developed in conjunction with the European Association of Echocardiography, a branch of the European Society of Cardiology. J Am Soc Echocardiogr 2005; 18:1440-1463.

23. Ciampi Q, Villari B. Role of echocardiography in diagnosis and risk stratification in heart failure with left ventricular systolic dysfunction. Cardiovasc Ultrasound 2007; 5:1-12.

24. Teichholz LE, Kreulen T, Herman MV, Gorlin R. Problems in echocardiographic volume determinations: echocardiographicangiographic correlations in the presence of absence of asynergy. Am J Cardiol 1976; 37:7-11.

25. Dias JCP, Machado EMM, Fernandes AL, Vinhaes MC. General situation and perspectives of Chagas disease in Northeastern Region, Brazil. Cad Saude Publica 2000; 16:13-34.

26. Prata A, Lopes ER, Chapadeiro E. Characteristics of unexpected sudden death in Chagas disease. Rev Soc Bras Med Trop 1986; 19:9-12.
27. Gontijo ED, Rocha MOC, Oliveira UT. Perfil clínicoepidemiológico de chagásicos atendidos em ambulatório de referência e proposição de modelo de atenção ao chagásico na perspectiva do SUS. Rev Soc Bras Med Trop 1996; 2:101-108.

28. Souza LRMF, Guariento ME. Evolução de pacientes chagásicos acompanhados em um serviço de referência. Rev Soc Bras Med Trop 1998; 31:54-55.

29. Bozelli CE, Araújo SM, Guilherme ALFG, Gomes ML. Perfil clínico-epidemiológico de pacientes com doença de Chagas no Hospital Universitário de Maringá, Paraná, Brasil. Cad Saude Publica 2006; 22:1027-1034.

30. Ribeiro ALP, Rocha MOC. Indeterminate form of Chagas disease: considerations about diagnosis and prognosis. Rev Soc Bras Med Trop 1998; 31:301-314.

31. Coura JR, Borges-Pereira J, Alves-Filho FI, Castro JAF, Cunha $\mathrm{RV}$, Costa W, et al. Morbidity of Chagas disease in areas of Sertão da Paraíba and Caatinga do Piauí. Rev Soc Bras Med Trop 1996; 29:197-205.

32. Castro C, Prata A, Macêdo V. A 13-year clinical study on 190 chronic chagasic patients from Mambaí, Goiás, Brazil. Rev Soc Bras Med Trop 2001; 34:309-318.

33. Hernandez EBR, Rezende JM, Macêdo V, Castro C. Estudo radiológico do cólon em indivíduos de área endêmica de doença de Chagas através da técnica simplificada de Ximenes. Rev Soc Bras Med Trop 2002; 35:188.

34. Köeberle F. Enteromegaly and cardiomegaly in Chagas disease. Gut 1963; 4:399-405.

35. Meneghelli UG. Chagasic enteropathy. Rev Soc Bras Med Trop 2004; 37:252-260.

36. Prata A. Clinical and epidemiological aspects of Chagas disease. Lancet Infect Dis 2001; 1:92-100.

37. Brener Z. Pathogenesis and immunopathology of chronic Chagas disease. Mem Inst Oswaldo Cruz 1987; 82:205-213.

38. Borges-Pereira J, Sarquis O, Zauza PL, Britto C, Lima MM. Epidemiologia da doença de Chagas em quatro localidades rurais de Jaguaruana, Estado do Ceará. Soroprevalência da infecção, parasitemia e aspectos clínicos. Rev Soc Bras Med Trop 2008; 41:345-351.

39. Rosas AF. Enfermedad de Chagas. Rev Colombiana Cardiol 2011; 18:241-244.

40. Borges-Pereira J, Zauza PL, Galhardo MC, Nogueira JS, Pereira GROL, Cunha RV. Doença de Chagas na população urbana do distrito sanitário de Rio Verde, Mato Grosso do Sul, Brasil. Rev Soc Bras Med Trop 2001; 34:459-466.

41. Aguilar VHM, Abad-Franch F, Racines VJ, Paucar CA. Epidemiology of Chagas disease in Ecuador. A brief review. Mem Inst Oswaldo Cruz 1999; 94:387-393.

42. Coura JR, Abreu LL, Dubois LEG, Lima FC, Arruda-Junior E, Willcox HPF, et al. Morbidade da doença de Chagas. II- Estudos seccionais em quarto áreas de campo no Brasil. Mem Inst Oswaldo Cruz 1984; 79:101-124.

43. Pompilio MA, Dorval MEMC, Cunha RV, Britto C, BorgesPereira J. Epidemiological, clinical and parasitological aspects of Chagas'disease in Mato Grosso do Sul State. Rev Soc Bras Med Trop 2005; 38:73-478.

44. Rocha MO, Ribeiro AL, Teixeira MM. Clinical management of chronic Chagas cardiomyopathy. Front Biosci 2003; 8:e44-54.

45. Brum-Soares LM, Xavier SS, Sousa AS, Borges-Pereira J, Ferreira JMBB, Costa IR, et al. Morbidity of Chagas disease among autochthonous patients from the Rio Negro microregion, State of Amazonas. Rev Soc Bras Med Trop 2010; 43:170-177. 
46. Mady C, Cardoso RHA, Barretto ACP, Luz PL, Bellotti G, Pileggi F. Survival and predictors of survival in patients with congestive heart failure due to Chagas' cardiomyopathy. Circulation 1994; 90:3098-3102.

47. Coura JR, Abreu LL, Borges-Pereira J, Willcox HP. Morbidity in Chagas' disease. IV. Longitudinal study of 10 years in Pains and Iguatama, Minas Gerais, Brazil. Mem Inst Oswaldo Cruz 1985; 80:73-80.

48. Acquatella H, Catalioti F, Gomez-Mancebo JR, Davalos V, Villalobos L. Long-term control of Chagas disease in Venezuela: effects on serologic findings, electrocardiographic abnormalities, and clinical outcome. Circulation 1987; 76:556-562.

49. Xavier SS, Sousa AS, Carvalho-Filho HA, Holanda MT, HasslocherMoreno A. Mecanismos de morte e função ventricular na fase crônica da doença de Chagas. Rev SOCERJ 2006; 19:239-246.

50. Ayub-Ferreira SM, Mangini S, Issa VS, Cruz FD, Bacal F, Guimarães GV, et al. Mode of death on Chagas heart disease: comparison with other etiologies. A subanalysis of the REMADHE prospective trial. PLoS Negl Trop Dis 2013; 7:1-10.

51. Prata SP, Cunha DF, Cunha SF, Prata SC, Nogueira N. Prevalence of electrocardiographic abnormalities in 2,000 aged and non-aged chagasic patients. Arq Bras Cardiol 1993; 60:369-372.

52. Rosenbaum MB, Alvarez AJ. The electrocardiogram in chronic chagasic myocarditis. Am Heart J 1955; 50:492-527.

53. Garzon SAC, Lorga AM, Nicolau JC. Eletrocardiografia na cardiopatia chagásica. Rev Soc Cardiol Estado de São Paulo 1994; 2:133-143.

54. Rassi-Junior A, Rassi SG, Rassi A. Sudden death in Chagas' disease. Arq Bras Cardiol 2001; 76:75-96.

55. Ortiz J, Barreto ACP, Matsumoto AY, Mônaco CAF, Ianni BM, Marotta RHQ, et al. Alteração contrátil segmentar na forma indeterminada da doença de Chagas. Estudo ecocardiográfico. Arq Bras Cardiol 1987; 49:217-220.

56. Barros ML, Ribeiro AL, Nunes MC, Rocha MOC. Association between left ventricular wall motion abnormalities and ventricular arrhythmia in the indeterminate form of Chagas disease. Rev Soc Bras Med Trop 2011; 44:213-216.

57. Borges-Pereira J, Xavier SS, Pirmez C, Coura JR. Chagas disease in Virgem da Lapa, Minas Gerais, Brazil. IV. Clinical and epidemiological aspects of left ventricular aneurism. Rev Soc Bras Med Trop 1998; 31:457-463.

58. Rassi-Junior A, Rassi A, Little WC, Xavier SS, Rassi SG, Rassi AG, et al. Development and validation of a risk score for predicting death in Chagas' heart disease. New Engl J Med 2006; 355: 799-808.

59. Sousa AS, Xavier SS, Freitas GR, Hasslocher-Moreno A. Prevention Strategies of Cardioembolic Ischemic Stroke in Chagas Disease. Arq Bras Cardiol 2008; 91:306-310.

60. Câmara ACJ, Lages-Silva E, Sampaio GHF, D’Ávila DA, Chiari E, Galvão LMC. Homogeneity of Trypanosoma cruzi I, II, and III populations and the overlap of wild and domestic transmission cycles by Triatoma brasiliensis in northeastern Brazil. Parasitol Res 2013; 112:1543-1550.

61. Poveda C, Fresno M, Gironès N, Martins-Filho AO, Ramírez JD, Santi-Rocca J, et al. Cytokine Profiling in Chagas Disease: Towards Understanding the Association with Infecting Trypanosoma cruzi Discrete Typing Units (A BENEFIT TRIAL Sub-Study). PloS One 2014; 9:1-8.

62. Coura JR. Epidemiologic determinants of Chagas' disease in Brazil: the infection, the disease and its morbidity/mortality. Mem Inst Oswaldo Cruz 1988; 83:392-402.

63. Guedes PMM, Gutierrez FRS, Silva GK, Dellalibera-Joviliano R, Rodrigues GJ, Bendhack LM, et al. Deficient regulatory T cell activity and low frequency of IL-17-producing $\mathrm{T}$ cells correlate with the extent of cardiomyopathy in human Chagas' disease. PLoS Negl Trop Dis 2012; 6:e1630.

64. Zicker F, Smith PG, Almeida-Netto JC, Oliveira RM, Zicker EM. Physical activity, opportunity for reinfection, and sibling history of heart disease as risk factors for Chagas' cardiopathy. Am J Trop Med Hyg 1990; 43:498-505. 